\title{
Multiple intracellular pathways for regulation of chloride secretion in cultured pig tracheal submucosal gland cells
}

\author{
A.-L. Zhang, G.M. Roomans
}

\begin{abstract}
Multiple intracellular pathways for regulation of chloride secretion in cultured pig tracheal submucosal gland cells. A.-L. Zhang, G.M. Roomans. (C)ES Journals Ltd 1999.

ABSTRACT: Tracheal submucosal glands are of great relative importance in the secretion of chloride and water to the airway lumen. This study aimed to examine whether the cystic fibrosis transmembrane conductance regulator (CFTR) is involved in cyclic adenosine monophosphate (cAMP) or $\mathrm{Ca}^{2+}$-activated $\mathrm{Cl}^{-}$secretion.

Regulation of $\mathrm{Cl}^{-}$secretion in cell cultures derived from pig tracheal submucosal gland acini was investigated by $\mathrm{X}$-ray microanalysis. With or without preincubation with CFTR antisense oligodeoxynucleotide $(5 \mu \mathrm{M})$.

A significant decrease in cellular $\mathrm{Cl}$ and $\mathrm{K}$ concentration was induced by $5 \mathrm{mM}$ 8-bromo-adenosine 3': 5'-cyclic monophosphate (8-bromo-cAMP), $3 \mu \mathrm{M}$ calcium ionophore ionomycin, $200 \mu M 5^{\prime}$-uridine triphosphate (UTP) and $200 \mu \mathbf{M}^{\prime}$-adenosine triphosphate (ATP), respectively. The decrease in cellular $\mathrm{Cl}$ content was significantly inhibited by the $\mathrm{Cl}^{-}$channel blocker 5-nitro-2-(3-phenylpropyl-amino)benzoic acid (NPPB; $50 \mu \mathrm{m})$. Preincubation of the cells with CFTR antisense oligodeoxynucleotide significantly inhibited the 8-bromo-cAMP-induced decrease in Cl, whereas CFTR sense oligodeoxynucleotide had no effect. The effects of ionomycin, ATP or UTP were not blocked by either CFTR antisense oligodeoxynucleotide or CFTR sense oligodeoxynueleotide. To measure the cytosolic free calcium concentration $\left(\left[\mathrm{Ca}^{2+}\right]_{i}\right)$ the cells grown on glass coverslips were loaded with fura-2 tetraoxymethylester (fura-2 AM; $5 \mu \mathrm{M}$ ). The $\left[\mathrm{Ca}^{2+}\right]_{i}$ was measured as the fluorescence ratio of emission $(340 / 380 \mathrm{~nm})$. Ionomycin $(3 \mu \mathrm{M})$ caused a rapid increase in $\left[\mathrm{Ca}^{2+}\right]_{\mathrm{i}}$ followed by a sustained plateau, but 8-bromo-cAMP had a more complex effect on $\left[\mathrm{Ca}^{2+}\right]_{\mathrm{i}}$. Exposure to ATP or UTP caused a rapid increase in $\left[\mathrm{Ca}^{2+}\right]_{i}$ followed by a decrease.

In conclusion, cystic adenosine monophosphate and ionomycin induced $\mathrm{Cl}^{-}$secretion through different intracellular pathways. Adenosine triphosphate and uridine triphosphate also induced $\mathrm{Cl}^{-}$secretion probably with $\mathrm{Ca}^{2+}$ as an intracellular messenger. The cystic fibrosis transmembrane conductance regulator is not involved in $\mathrm{Cl}^{-}$secretion activated by extracellular adenosine triphosphate and uridine triphosphate.

Eur Respir J 1999; 13: 571-576.
\end{abstract}

Dept of Human Anatomy, University of Uppsala, Uppsala, Sweden.

Correspondence: G.M. Roomans

Dept of Human Anatomy

University of Uppsala

Box 571

S-751 23 Uppsala

Sweden

Fax: 4618551120

Keywords: Airway submucosal gland chloride secretion

cystic fibrosis transmembrane

conductance regulator

cytosolic free calcium concentration

nucleotide

X-ray microanalysis

Received: January 161998

Accepted after revision October 251998

This study was financially supported by grants from the Swedish Heart-Lung Foundation, Society of Medical Research, and the Swedish Medical Council (project 07125).
Cystic fibrosis (CF) is the most common lethal genetic disease in the Caucasian population. The disease is characterized by defective ion transport in airways [1-4], exocrine glands [5], and other organs. The CF gene was cloned in 1989 [6]. The cystic fibrosis transmembrane conductance regulator (CFTR) coded by the CF gene is a cyclic adenosine monophosphate (cAMP)-dependent chloride channel [7]. The defect in the protein product coded by the mutated $\mathrm{CF}$ gene is the molecular basis of the decreased $\mathrm{Cl}^{-}$permeability of the apical plasma membrane of airway and other epithelial cells. The increased $\mathrm{Na}^{+}$ absorption by the airway epithelium is another characteristic of $\mathrm{CF}[1,3,4]$, but the relation between the hyperabsorption of $\mathrm{Na}^{+}$and the defective CFTR is not yet clear. A low level of CFTR expression was observed in the surface epithelium of the human bronchus, and a much higher level of CFTR was demonstrated in the cells of the ciliated ducts, the collecting ducts and the serous tubules of the bronchial submucosal glands [8]. CFTR was consis- tently localized to the apical membrane of these cells. The location of CFTR implies that it can serve as a chloride channel in the airway submucosal glands. In a previous report, using X-ray microanalysis it was demonstrated that both cAMP and the $\mathrm{Ca}^{2+}$ ionophore ionomycin induced $\mathrm{Cl}^{-}$secretion in cell cultures of acinar cells from pig tracheal submucosal glands. However, it is not known whether CFTR is involved in cAMP- or $\mathrm{Ca}^{2+}$-activated $\mathrm{Cl}^{-}$ secretion in the cultured cells.

The antisense technique has been developed to inhibit or block protein expression in order to study the function of the target protein, or possibly to treat some diseases clinically. The designed antisense oligodeoxynucleotide can bind to specific messenger ribonucleic acid (mRNA) and block the expression of the target protein at the translation level. This technique has been successfully applied to confer a CF phenotype onto normal cultured sweat duct cells [9] and colonic and tracheal epithelial cell lines [10] using CFTR antisense oligodeoxynucleotide. In the present 
study, before exposure to cAMP or ionomycin, the cultured cells, grown on a permeable substrate, were incubated with CFTR antisense oligodeoxynucleotide to lower the amount of CFTR in order to investigate the role of CFTR in cAMP- or $\mathrm{Ca}^{2+}$-induced $\mathrm{Cl}^{-}$secretion.

In contrast to the defective cAMP-dependent pathway, the $\mathrm{Ca}^{2+}$-dependent pathway of $\mathrm{Cl}^{-}$secretion is preserved in CF airway surface epithelium $[11,12]$. The extracellular nucleotides adenosine 5 -triphosphate (ATP) and uridine 5 -triphosphate (UTP) could induce $\mathrm{Cl}^{-}$secretion in normal and CF nasal surface epithelia $[13,14]$ which is likely to be through elevated intracellular $\mathrm{Ca}^{2+}[14]$. Over the last few years, UTP has been clinically tested in an attempt to bypass the CF defect. This substance could have a possible therapeutic effect on the lung disease in CF [15]. The regulatory effects of ATP and UTP on ion transport in cell cultures of pig tracheal submucosal glands were therefore studied.

\section{Materials and methods}

\section{Materials and solutions}

5-Nitro-2-(3-phenylpropyl-amino)-benzoic acid (NPPB) was a kind gift from H.C. Englert, Hoechst AG, Freiburg, Germany. Unless otherwise stated, all drugs and reagents were purchased from Sigma Chemical Co. (St Louis, MO, USA) or from Gibco BRL/Life Technologies (Paisley, UK). Krebs-HEPES (N-2-hydroxyethylpiperazine-N'-2-ethanesulphonic acid) solution (KHS; $\mathrm{pH} 7.4$ ) consisted of (in $\mathrm{mM}): 120 \mathrm{NaCl}, 4 \mathrm{KCl}, 1.2 \mathrm{MgSO}_{4}, 1.2 \mathrm{KH}_{2} \mathrm{PO}_{4}$ and 15 HEPES. Standard Ringer's solution (SRS; pH 7.4) contained (in $\mathrm{mM}$ ) $140 \mathrm{NaCl}, 5 \mathrm{KCl}, 5 \mathrm{HEPES}, 1 \mathrm{MgCl}_{2}, 1.5$ $\mathrm{CaCl}_{2}$ and 5 glucose.

\section{Cell culture}

Acinar cells were isolated and cultured as previously described [16]. Briefly, submucosal tissue was collected after the surface epithelium was removed by sharp dissection, then digested for $2 \mathrm{~h}$ at $37^{\circ} \mathrm{C}$ in digesting medium containing $20 \mathrm{mM}$ HEPES, type IV collagenase (500 $\left.\mathrm{U} \cdot \mathrm{mL}^{-1}\right)$, pancreatic porcine elastase $\left(6 \mathrm{U} \cdot \mathrm{mL}^{-1}\right)$, hyaluronidase $\left(200 \mathrm{U} \cdot \mathrm{mL}^{-1}\right)$ and deoxyribonuclease $\left(10 \mathrm{U} \cdot \mathrm{mL}^{-1}\right)$. The clusters of acinar cells were picked up under a phase contrast microscope and cultured on a human placental collagen-coated Petri dish at $37^{\circ} \mathrm{C}$ in $5 \% \mathrm{CO}_{2} / 95 \%$ air. The cell culture medium was composed of $49 \%$ Dulbecco's modified eagle medium (DMEM), 49\% Ham's F12 medium and $2 \%$ Ultroser $\mathrm{G}$. The cultured cells were detached by trypsin when the cultures reached confluence, and then seeded on titanium grids (Agar Scientific, Stansted, UK) for X-ray microanalysis or on glass coverslips for measurement of cytosolic free calcium by fluorescent probes.

\section{Antisense oligodeoxynucleotide treatment}

Antisense oligodeoxynucleotide treatment has been used to suppress the expression of specific genes [17] in order to investigate the functions of the proteins. Antisense oligomers are typically directed to the initial nucleotides of the target mRNA. A 23-mer oligodeoxynucleotide complementary (antisense) to the human CFTR transcript and a 23-mer oligodeoxynucleotide homologous (sense control) to this transcript [6] were purchased from Scandinavian Gene Synthesis AB (Köping, Sweden). Both were phosphorothioate-modified oligodeoxynucleotides to increase cellular uptake [18] and were resistant to nucleases [19]. Either the antisense oligodeoxynucleotide, 5'-CAGAGGCGACCTCTGCAT-3', or the sense oligodeoxynucleotide, 5'-ATGCAGAGGTCGCCTCTG-3', was added to the cell culture medium $48 \mathrm{~h}$ prior to 8-bromo-cAMP, ionomycin, ATP or UTP exposure; the final concentration of oligodeoxynucleotide was $5 \mu \mathrm{M}$.

\section{Preparation for X-ray microanalysis}

Cells were cultured on titanium grids covered with a Formvar (Merck, Darmstadt, Germany) film for 4-6 days. When the culture reached confluence, the cells were incubated with SRS containing 8-bromo-cAMP ionomycin, ATP or UTP (table 1). In some experiments, the effect of different $\mathrm{Cl}^{-}$channel blockers: NPPB or anthracene-9carboxylic acid (9-AC), was tested. The cell-covered grids were preincubated with one of the $\mathrm{Cl}^{-}$channel blockers followed by incubation with one of the agents described above in the presence of this $\mathrm{Cl}^{-}$channel blocker (table 1). In other experiments, after cells were cultured on titanium grids for 2-4 days and when the cultures were close to confluence ( $70-80 \%$ confluence), CFTR antisense or sense oligodeoxynucleotide were added to the cell culture medium at a final concentration of 5 $\mu \mathrm{M}$. After $48 \mathrm{~h}$, the cells were treated with 8-bromocAMP, ionomycin, ATP and UTP, respectively (table 1). The dose of the agents used in this study is close to the known maximum dose for this or similar cell types. The cells incubated with only SRS (for 3 or $5 \mathrm{~min}$ ), 1\% dimethylsulphoxide (DMSO) in SRS (for $3 \mathrm{~min}$ ), $50 \mu \mathrm{M}$ NPPB or $500 \mu \mathrm{M}$ 9-AC (for 5 or $7 \mathrm{~min}$ ) were used as controls. The incubation was terminated by a quick rinse with SRS and the cells were then washed with cold distilled water for 2-3 s to remove the salt-rich SRS. After rinsing, the grids were quickly frozen in liquid propane cooled by liquid nitrogen $\left(-180^{\circ} \mathrm{C}\right)$ and freeze-dried overnight in vacuum at $-80^{\circ} \mathrm{C}$. The freeze-dried specimens were covered with a conductive carbon layer before analysis.

\section{X-ray microanalysis}

The specimens were analysed in an electron microscope (Hitachi H7100, Tokyo, Japan) in the scanning-transmission electron microscopy (STEM) mode at $100 \mathrm{kV}$ with an Oxford Instruments (Oxford, UK) ISIS energy-dispersive spectrometer system. Quantitative analysis was carried out by determining the ratio of characteristic counts to the background under the peak $(\mathrm{P} / \mathrm{B})$, and by comparing the $\mathrm{P} /$ $\mathrm{B}$ ratios from the cells with those from standards consisting of a gelatin/glycerol matrix containing mineral salts in known concentrations [20]. Spectra were acquired for 100 s. Only one spectrum was acquired from each cell.

\section{Measurement of cytosolic free calcium}

Cells on 12-13 mm glass coverslips were grown for 4-6 days, and then loaded with $5 \mu \mathrm{M}$ fura- 2 tetraoxymethylester in the culture medium [21] at $37^{\circ} \mathrm{C}$ for $30 \mathrm{~min}$ 
Table 1. - Preincubation and incubation of cultured pig tracheal submucosal gland cells

\begin{tabular}{|c|c|c|c|c|c|}
\hline $\begin{array}{l}\text { Added during } \\
\text { preincubation }\end{array}$ & $\begin{array}{c}\text { Concentration } \\
\mu \mathrm{M}\end{array}$ & $\begin{array}{c}\text { Preincubation } \\
\text { time }\end{array}$ & $\begin{array}{l}\text { Added during } \\
\text { incubation }\end{array}$ & Concentration & $\begin{array}{l}\text { Incubation time } \\
\text { min }\end{array}$ \\
\hline - & - & - & 8-Bromo-cAMP & $5 \mathrm{mM}$ & 3 \\
\hline NPPB & 50 & $2 \min$ & $\begin{array}{l}\text { 8-Bromo-cAMP } \\
+ \text { NPPB }\end{array}$ & $\begin{array}{r}5 \mathrm{mM} \\
50 \mu \mathrm{M}\end{array}$ & 3 \\
\hline 9-AC & 500 & $2 \mathrm{~min}$ & $\begin{array}{l}\text { 8-Bromo-cAMP } \\
+9-\mathrm{AC}\end{array}$ & $\begin{array}{r}5 \mathrm{mM} \\
500 \mu \mathrm{M}\end{array}$ & 3 \\
\hline- & - & - & Ionomycin & $3 \mu \mathrm{M}$ & 3 \\
\hline NPPB & 50 & $2 \mathrm{~min}$ & $\begin{array}{c}\text { Ionomycin } \\
+ \text { NPPB }\end{array}$ & $\begin{array}{r}3 \mu \mathrm{M} \\
50 \mu \mathrm{M}\end{array}$ & 3 \\
\hline 9-AC & 500 & $2 \mathrm{~min}$ & $\begin{array}{l}\text { Ionomycin } \\
+9-\mathrm{AC}\end{array}$ & $\begin{array}{r}3 \mu \mathrm{M} \\
500 \mu \mathrm{M}\end{array}$ & 3 \\
\hline- & - & - & ATP & $200 \mu \mathrm{M}$ & 5 \\
\hline NPPB & 50 & $2 \mathrm{~min}$ & $\begin{array}{c}\text { ATP } \\
+ \text { NPPB }\end{array}$ & $\begin{array}{r}200 \mu \mathrm{M} \\
50 \mu \mathrm{M}\end{array}$ & 5 \\
\hline $9-\mathrm{AC}$ & 500 & $2 \mathrm{~min}$ & $\begin{array}{c}\text { ATP } \\
+9-\mathrm{AC}\end{array}$ & $\begin{array}{l}200 \mu \mathrm{M} \\
500 \mu \mathrm{M}\end{array}$ & 5 \\
\hline - & - & - & UTP & $200 \mu \mathrm{M}$ & 5 \\
\hline NPPB & 50 & $2 \mathrm{~min}$ & $\begin{aligned} & \text { UTP } \\
+ & \text { NPPB }\end{aligned}$ & $\begin{array}{r}200 \mu \mathrm{M} \\
50 \mu \mathrm{M}\end{array}$ & 5 \\
\hline 9-AC & 500 & $2 \mathrm{~min}$ & $\begin{array}{c}\text { UTP } \\
+9-A C\end{array}$ & $\begin{array}{l}200 \mu \mathrm{M} \\
500 \mu \mathrm{M}\end{array}$ & 5 \\
\hline CFTR sense oligomer & 5 & $48 \mathrm{~h}$ & 8-Bromo-cAMP & $5 \mathrm{mM}$ & 3 \\
\hline CFTR sense oligomer & 5 & $48 \mathrm{~h}$ & Ionomycin & $3 \mu \mathrm{M}$ & 3 \\
\hline CFTR antisense oligomer & 5 & $48 \mathrm{~h}$ & 8-Bromo-cAMP & $5 \mathrm{mM}$ & 3 \\
\hline CFTR antisense oligomer & 5 & $48 \mathrm{~h}$ & Ionomycin & $3 \mu \mathrm{M}$ & 3 \\
\hline CFTR sense oligomer & 5 & $48 \mathrm{~h}$ & ATP & $200 \mu \mathrm{M}$ & 5 \\
\hline CFTR sense oligomer & 5 & $48 \mathrm{~h}$ & UTP & $200 \mu \mathrm{M}$ & 5 \\
\hline CFTR antisense oligomer & 5 & $48 \mathrm{~h}$ & ATP & $200 \mu \mathrm{M}$ & 5 \\
\hline CFTR antisense oligomer & 5 & $48 \mathrm{~h}$ & UTP & $200 \mu \mathrm{M}$ & 5 \\
\hline
\end{tabular}

NPPB: 5-nitro-2-(3-phenylpropyl-amino)-benzoic acid; 9-AC: anthracene-9-carboxylic acid; CFTR: cystic fibrosis transmembrane conductance regulator; 8-bromo-cAMP: 8-bromoadenosine $3^{\prime}: 5^{\prime}$-cyclic monophosphate; ATP: adenosine $5^{\prime}$-triphosphate; UTP: uridine 5 '-triphosphate.

(Molecular Probes, Junction City, OR, USA). After rinsing thoroughly with SRS, the coverslips were mounted in a chamber on top of another glass coverslip (25 $\mathrm{mm}$ in diameter). The chamber containing SRS and the cells was placed on the stage of an inverted microscope (Nikon Diaphot 300, Tokyo, Japan). Excitation was switched automatically by an excitation filter changer (Applied Imaging, Sunderland, UK) between 340 and $380 \mathrm{~nm}$; the emission was through a dichroic reflector and was measured at $510 \mathrm{~nm}$. The fluorescent image was detected by a charge-coupled device (CCD) camera and the camera output was fed to an image-processing system (Applied Imaging). Fluorescent images of single cells could be recognized, selected and quantified. The intracellular free calcium was measured as the fluorescence ratio resulting from excitation with light at 340 and $380 \mathrm{~nm}$. The ratio signal was not converted to a calcium concentration. The measuring procedure was carried out at room temperature. Usually about 10 cells in one sample were selected. To investigate the regulatory effects on cytosolic $\mathrm{Ca}^{2+}$ concentration of some agents, the stock solution in SRS was added into the chamber containing the cells and SRS.

\section{Statistical analysis}

Student's t-test was used to evaluate the statistical significance of changes in the elemental content. Significance was attributed to $p$-values of $<0.05$.

\section{Results}

The elemental composition in the control cultures is shown in table 2. A significant decrease in intracellular $\mathrm{K}$ and $\mathrm{Cl}$ content was observed after exposure of the cells to 8-bromo-cAMP, ionomycin, UTP and ATP. The loss of $\mathrm{Cl}^{-}$and $\mathrm{K}^{+}$from the cells was significantly inhibited by NPPB (figs. 1 and 2) whereas 9-AC had no effect (data not shown).

The cellular elemental composition (table 2) was not significantly affected by preincubation of the cells with CFTR antisense or sense oligomer (data not shown). Both 8-bromo-cAMP and ionomycin induced a significant decrease in the $\mathrm{Cl}$ and $\mathrm{K}$ content in the CFTR sense oligomer-treated cells. In the CFTR antisense oligomertreated cells, the $\mathrm{K}$ concentration significantly decreased

Table 2. - The elemental composition of the cultured tracheal gland cells (control)

\begin{tabular}{lc}
\hline Element & Concentration mmol.dg dry weight ${ }^{-1}$ \\
\hline $\mathrm{Na}$ & $70 \pm 9$ \\
$\mathrm{Mg}$ & $25 \pm 3$ \\
$\mathrm{P}$ & $550 \pm 27$ \\
$\mathrm{~S}$ & $137 \pm 11$ \\
$\mathrm{Cl}$ & $209 \pm 18$ \\
$\mathrm{~K}$ & $739 \pm 25$ \\
\hline
\end{tabular}

Results are given as mean \pm SEM. The data are based on four independent experiments using cell cultures set up from three pigs, in which 80 cells were analysed. 


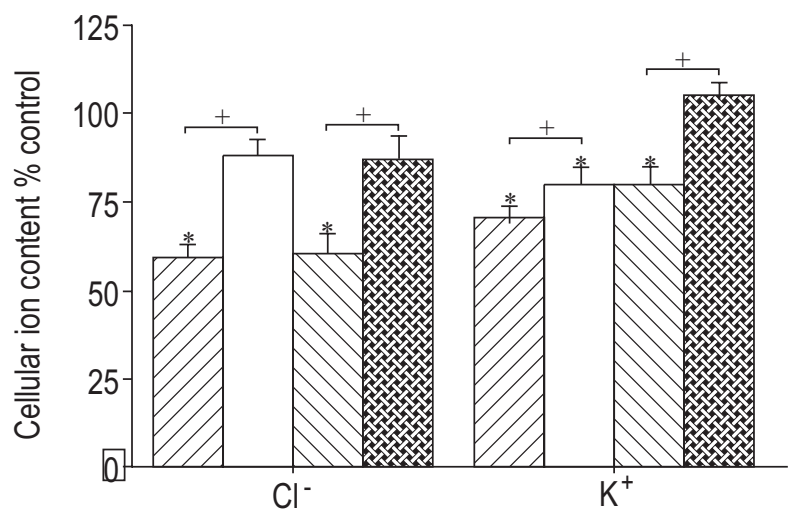

Fig. 1. - Effect of 8-bromocyclic adenosine monophosphate (cAMP) and ionomycin on the cellular content of $\mathrm{K}$ and $\mathrm{Cl}$ in cultured pig tracheal submucosal gland acinar cells, and inhibition by 5-nitro-2-(3phenylpropyl-amino)-benzoic acid (NPPB) of $\mathrm{K}^{+}$and $\mathrm{Cl}^{-}$secretion. The data are expressed as a percentage of the control value as means \pm SEM. *: $\mathrm{p}<0.05$, statistical significance of the difference from the control. ${ }^{+}$: $\mathrm{p}<0.05$, significant difference between two groups. The data are based on four experiments using cell cultures set up from three pigs, in each experiment about 15 cells were analysed. $\mathbb{Q}: 5 \mathrm{mM}$ cAMP; $\square: 5 \mathrm{mM}$ cAMP $+50 \mu \mathrm{M}$ NPPB; $\mathbb{Z}: 3 \mu \mathrm{M}$ ionomycin; $: 3 \mu \mathrm{M}$ ionomycin +50 $\mu \mathrm{M}$ NPPB.

after 8-bromo-cAMP or ionomycin addition, but the decrease in the $\mathrm{Cl}$ concentration was observed only after ionomycin treatment. Thus, CFTR antisense oligomer treatment significantly inhibited 8-bromo-cAMP-induced $\mathrm{Cl}^{-}$ secretion in the cultured cells (fig. 3).

The preincubation of the cultured cells with CFTR sense or antisense oligodeoxynucleotide did not affect the effects of ATP or UTP on the $\mathrm{Cl}^{-}$and $\mathrm{K}^{+}$efflux (fig. 4).

The concentration of cytosolic free calcium $\left(\left[\mathrm{Ca}^{2+}\right]_{\mathrm{i}}\right)$ was monitored by the fura-2 fluorescence ratio. Exposure to ionomycin caused a rapid elevation in $\left[\mathrm{Ca}^{2+}\right]_{\mathrm{i}}$ followed by a prolonged plateau (fig. 5, trace a). The cells did not respond uniformly to 8 -bromo-cAMP. $\left[\mathrm{Ca}^{2+}\right]_{\mathrm{i}}$ did not change in 35 out of 89 cells studied (fig. 5 , trace c); a slight decrease in $\left[\mathrm{Ca}^{2+}\right]_{\mathrm{i}}$ was observed in 14 cells where-

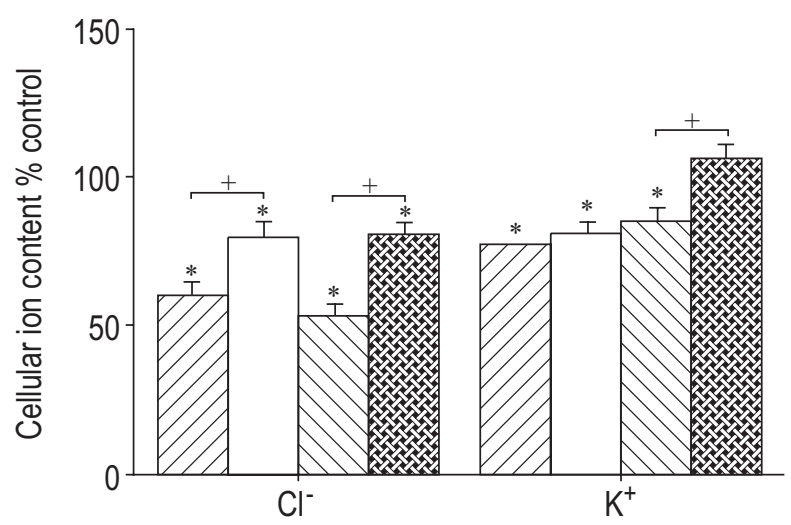

Fig. 2. - Effect of adenosine triphosphate (ATP) and uridine triphosphate (UTP) on the cellular content of $\mathrm{K}$ and $\mathrm{Cl}$ in cultured pig tracheal submucosal gland acinar cells, and inhibition by 5-nitro-2-(3-phenylpropyl-amino)-benzoic acid (NPPB) of $\mathrm{K}^{+}$and $\mathrm{Cl}^{-}$efflux. The data are expressed as a percentage of the control value as means \pm SEM. $*: p<0.05$, statistical significance of the difference from control. ${ }^{+}: \mathrm{p}<0.05$, significant difference between two groups. The data are based on three experiments using cell cultures set up from two pigs, in each experiment about 15 cells were analysed. $\mathbb{Q}: 200 \mu \mathrm{M}$ ATP; $\square: 200 \mu \mathrm{M}$ ATP +50 $\mu \mathrm{M}$ NPPB; $\mathbb{Z}: 200 \mu \mathrm{M}$ UTP; $: 200 \mu \mathrm{M}$ UTP + $50 \mu \mathrm{M}$ NPPB.

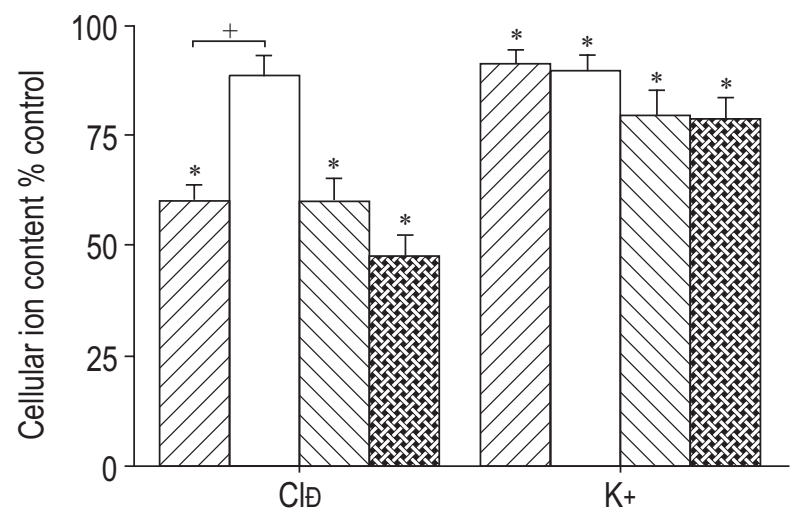

Fig. 3. - Effect of the cystic fibrosis transmembrane conductance regulator antisense (and sense control) oligodeoxynucleotide on the change in the $\mathrm{Cl}$ and $\mathrm{K}$ content induced by 8-bromo-cyclic adenosine monophosphate (cAMP) and ionomycin. The data are expressed as a percentage of the control value as means \pm SEM. ${ }^{*}: \mathrm{p}<0.05$, statistical significance of the difference from the control. ${ }^{+}: \mathrm{p}<0.05$, significant difference between two groups. The data are based on three experiments using cell cultures set up from three pigs, in each experiment about 15 cells were analysed. $\mathbb{Q}: 5 \mu \mathrm{M}$ sense oligomer $+5 \mathrm{mM}$ cAMP; $\square: 5 \mu \mathrm{M}$ antisense oligomer $+5 \mathrm{mM}$ cAMP; $\mathbb{Z}: 5 \mu \mathrm{M}$ sense oligomer $+3 \mu \mathrm{M}$ ionomycin; : $5 \mu \mathrm{M}$ antisense oligomer $+3 \mu \mathrm{M}$ ionomycin.

as $\left[\mathrm{Ca}^{2+}\right]_{\mathrm{i}}$ slightly increased in 40 cells (fig. 5, trace b). The response of cells to ATP was similar to that to UTP, namely a rapid and transient elevation of $\left[\mathrm{Ca}^{2+}\right]_{\mathrm{i}}$ followed by a slow decrease, as illustrated in figure 6 .

\section{Discussion}

The data show that incubation of cultured tracheal submucosal gland cells with cAMP or ionomycin caused a significant decrease in the cellular $\mathrm{Cl}$ and $\mathrm{K}$ content, which was significantly inhibited by the $\mathrm{Cl}^{-}$channel blocker NPPB (fig. 1). These results indicate that the decrease in the $\mathrm{Cl}$ content is due to $\mathrm{Cl}^{-}$secretion rather than inhibition of $\mathrm{Cl}^{-}$uptake. As with other epithelia, the cultured cells

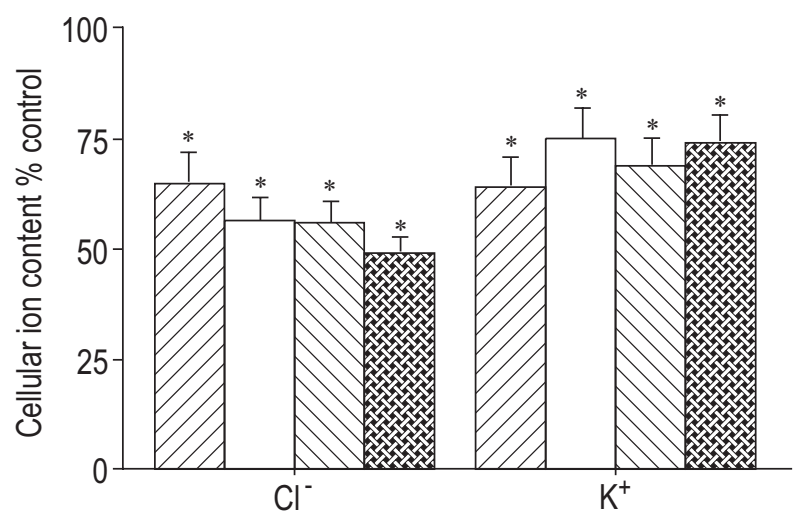

Fig. 4. - Effect of the cystic fibrosis transmembrane conductance regulator antisense (and sense control) oligodeoxynucleotide on the change in the $\mathrm{Cl}$ and $\mathrm{K}$ content induced by adenosine triphosphate (ATP) and uridine triphosphate (UTP). The data are expressed as a percentage of the control value as means \pm SEM. $*: \mathrm{p}<0.05$, statistical significance of the difference from the control. The data are based on three experiments using cell cultures set up from three pigs, in each experiment about 15 cells were analysed. $\mathbb{Q}: 5 \mu \mathrm{M}$ sense oligomer $+200 \mu \mathrm{M}$ ATP; $\square: 5 \mu \mathrm{M}$ antisense oligomer $+200 \mu \mathrm{M}$ ATP; $\mathbb{Z}: 5 \mu \mathrm{M}$ sense oligomer $+200 \mu \mathrm{M}$ UTP; $: 5 \mu \mathrm{M}$ antisense + oligomer $+200 \mu \mathrm{M}$ UTP. 


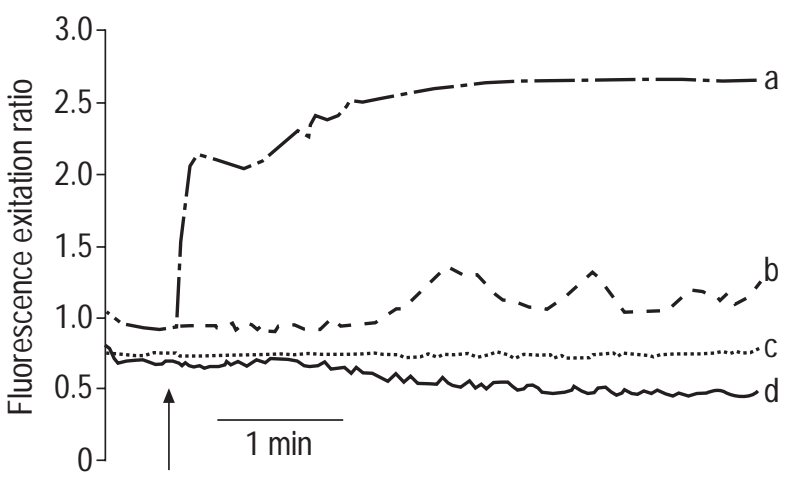

Fig. 5. - Effect of ionomycin and 8-bromo-cyclic adenosine monophosphate (cAMP) on cytosolic free calcium in the cultured cells (control). The addition of ionomycin $(3 \mu \mathrm{M})$ and 8-bromo-cAMP $(5 \mathrm{mM})$ is indicated by the arrow. The response shown by trace (a) is representative for all 60 cells treated with ionomycin, trace (b) is representative for 40 out of 89 studied cells, trace (c) is representative for 35 out of 89 cells and trace $(\mathrm{d})$ is representative for 14 out of 89 cells.

released not only $\mathrm{Cl}^{-}$but also $\mathrm{K}^{+}$upon stimulation [22]. The mechanism underlying NPPB inhibition of $\mathrm{K}^{+}$efflux is not clear. The $\mathrm{Ca}^{2+}$-dependent pathway of $\mathrm{Cl}^{-}$secretion has been demonstrated in cat [23] and human [24] tracheobronchial gland cells in primary culture, and in freshly isolated pig [25] and human [26] tracheal gland cells. The observation in this study that $\left[\mathrm{Ca}^{2+}\right]_{\mathrm{i}}$ clearly increased after ionomycin addition indicates that a $\mathrm{Ca}^{2+}$-activated pathway of $\mathrm{Cl}^{-}$secretion exists in the cultured cells. $\mathrm{Cl}^{-}$secretion in cell cultures caused by the $\beta$-adrenergic agonist isoproterenol has previously been demonstrated [16]. YAMAYA et al. [24] also showed that isoproterenol induced $\mathrm{Cl}^{-}$secretion in primary culture of human tracheobronchial gland cells, which is in line with the present results because isoproterenol is presumed to act via cAMP as an intracellular messenger. Since a cAMP-induced increase in $\left[\mathrm{Ca}^{2+}\right]_{i}$ was shown in primary cultures of canine tracheal surface epithelial cells [27], the effect of cAMP on $\left[\mathrm{Ca}^{2+}\right]_{\mathrm{i}}$ was investigated. As illustrated in figure 5 , the cytosolic $\mathrm{Ca}^{2+}$ concentration changed only slightly or not at all after addition of cAMP to the incubation medium. Considering that cAMP induced $\mathrm{Cl}^{-}$secretion to the same extent as ionomycin (fig. 1), another $\mathrm{Ca}^{2+}$-independent intracellular pathway of $\mathrm{Cl}^{-}$secretion seems to exist in these cells. This

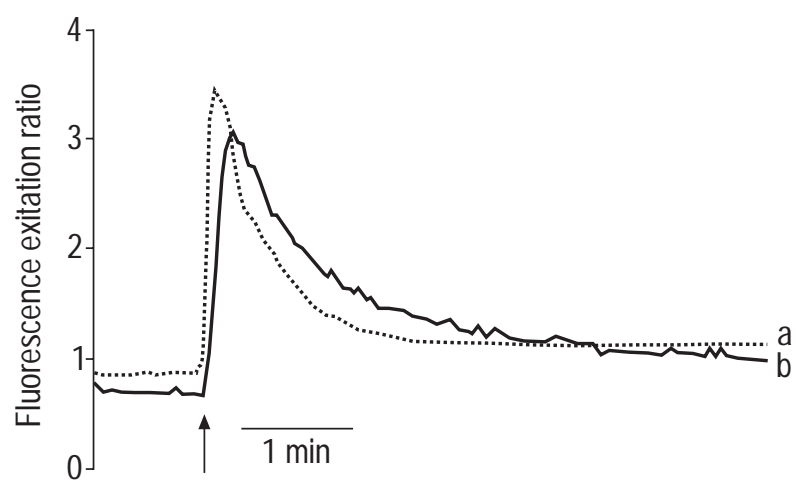

Fig. 6. - Effect of adenosine triphosphate (ATP) and uridine triphosphate (UTP) on cytosolic free calcium in the cultured cells (control). The addition of ATP $(200 \mu \mathrm{M})$ and UTP $(200 \mu \mathrm{M})$ is indicated by the arrow. The response shown by trace (a) is representative for all 34 cells treated with ATP, trace (b) is representative for all 46 cells treated with UTP. pathway possibly works via cAMP/protein kinase A (PKA). These results imply that both cAMP and $\mathrm{Ca}^{2+}$ dependent pathways of $\mathrm{Cl}^{-}$secretion exist in the cultured cells.

A low level of CFTR expression has been observed in the surface epithelium of the human bronchus, and a much higher level of CFTR has been demonstrated in the bronchial submucosal glands [8]. It is widely accepted that CFTR in human airway surface epithelial cells serves as the $\mathrm{Cl}^{-}$channel, and this channel is defective in $\mathrm{CF}$ patients. So far, to the authors' knowledge, CFTR expression in pig airway submucosal glands has not been studied. However, CFTR expression is not limited to humans, but is, for example, also found in mice [28]. Therefore, it was hypothesized that CFTR is expressed in pig airway submucosal glands, and in this study, an antisense technique was employed to test whether or not CFTR is involved in cAMP- and $\mathrm{Ca}^{2+}$-activated $\mathrm{Cl}^{-}$secretion in the cells. CFTR antisense oligodeoxynucleotide treatment inhibited cAMPactivated $\mathrm{Cl}^{-}$secretion whereas $\mathrm{Ca}^{2+}$-activated $\mathrm{Cl}^{-}$secretion was not affected (fig. 3). The CFTR antisense oligomer did not affect the $\mathrm{K}^{+}$efflux following stimulation with cAMP or ionomycin (fig. 3). These results support the hypothesis that CFTR is expressed in the cells and is an element of the cAMP-activated pathway of $\mathrm{Cl}^{-}$secretion. The results also indicate that CFTR is not relevant to $\mathrm{Ca}^{2+}$-activated $\mathrm{Cl}^{-}$ secretion in the cells $[9,10]$. CFTR likely serves as the $\mathrm{Cl}^{-}$ channel in airway gland cells since CFTR was consistently localized to the apical membrane of serous tubules of human airway submucosal glands [8]. Since the earliest pathological changes in the lungs of CF infants are dilatation of the submucosal gland ducts by retained secretions, it is believed that the airway submucosal glands significantly contribute to the airway secretion and play an important role in CF. However, there are only few studies on ion transport in CF airway submucosal glands. One report [29] claims that both cAMP and $\mathrm{Ca}^{2+}$-dependent mechanisms of $\mathrm{Cl}^{-}$secretion are defective.

Cell cultures derived from human tracheal submucosal glands released $\mathrm{Cl}^{-}$and $\mathrm{K}^{+}$in response to extracellular ATP or UTP similar to surface epithelia of human airways [14]; exposure to these two nucleotides also caused an increase in $\left[\mathrm{Ca}^{2+}\right]_{i}[30]$. In the present study, the cultured cells responded to extracellular ATP or UTP by releasing $\mathrm{Cl}^{-}$(and $\mathrm{K}^{+}$) (fig. 2), and it was also shown that $\left[\mathrm{Ca}^{2+}\right]_{\mathrm{i}}$ clearly increased after addition of ATP or UTP to the incubation medium (fig. 6). It was concluded that ATP and UTP induced $\mathrm{Cl}^{-}$secretion in the cells probably through a $\mathrm{Ca}^{2+}$-dependent pathway. This result also agrees with a study using the patch-clamp technique [31], in which ATP evoked an initial inward current $\left(\mathrm{Cl}^{-}\right.$current) followed by an outward current $\left(\mathrm{K}^{+}\right.$current). The preincubation of the cells with CFTR antisense oligomer blocked cAMP-dependent $\mathrm{Cl}^{-}$secretion, conferring a CF-like phenotype on the cells. ATP and UTP were able to stimulate $\mathrm{Cl}^{-}$secretion in the antisense oligomer-treated cells (fig. 4). This implies that ATP and UTP regulate $\mathrm{Cl}^{-}$transport in the cells via an CFTR-independent pathway probably with $\mathrm{Ca}^{2+}$ as a second messenger. Based on this finding, it is reasonable to expect that ATP and UTP could activate $\mathrm{Cl}^{-}$secretion in $\mathrm{CF}$ airway submucosal glands. Inhalation of UTP/amiloride has been tested as a therapy of CF. It has been shown that UTP/amiloride improved mucociliary clearance in normal human adults and adult CF patients [15] without 
evident side-effects. It is not easy to evaluate the effect of inhaled UTP/amiloride on the airway submucosal glands in situ, but it is apparent that optimal treatment of CF should also cover the airway submucosal glands.

\begin{abstract}
Acknowledgements. The authors gratefully acknowledge the expert technical assistance of A. Ahlander, M. Ljungquist and L. Ljung.
\end{abstract}

\section{References}

1. Knowles MR, Stutts MJ, Spock A, Fisher N, Gatzy JT, Boucher RC. Abnormal ion permeation through cystic fibrosis respiratory epithelium. Science 1983; 221: 1067 1070.

2. Widdicombe JH, Welsh MJ, Finkbeiner WE. Cystic fibrosis decreases the apical membrane chloride permeability of monolayers cultured from cells of tracheal epithelium. Proc Natl Acad Sci USA 1985; 82: 61676171.

3. Boucher RC, Stutts MJ, Knowles MR, Cantley L, Gatzy JT. $\mathrm{Na}^{+}$transport in cystic fibrosis respiratory epithelia: abnormal basal rate and response to adenylate cyclase activation. J Clin Invest 1986; 78: 1245-1252.

4. Boucher RC, Cotton CU, Gatzy JT, Knowles MR, Yankaskas JR. Evidence for reduced $\mathrm{Cl}^{-}$and increased $\mathrm{Na}^{+}$permeability in cystic fibrosis human primary cell cultures. J Physiol Lond 1988; 405: 77-103.

5. Quinton PM. Chloride impermeability in cystic fibrosis. Nature 1983; 301: 421-422.

6. Riordan JR, Rommens JM, Kerem BS, et al. Identification of the cystic fibrosis gene: cloning and characterisation of complementary DNA. Science 1989; 245: 1066-1072.

7. Bear $\mathrm{CE}, \mathrm{Li} \mathrm{CH}$, Kartner N, et al. Purification and functional reconstitution of the cystic fibrosis transmembrane conductance regulator (CFTR). Cell 1989; 68: 809-818.

8. Engelhardt JF, Yankaskas JR, Ernst SA, et al. Submucosal glands are the predominant site of CFTR expression in the human bronchus. Nat Genet 1992; 2: 240-248.

9. Sorscher EJ, Kirk KL, Weaver ML, Jilling T, Blalock E, LeBoeuf RD. Antisense oligodeoxynucleotide to the cystic fibrosis gene inhibits anion transport in normal cultured sweat duct cells. Proc Natl Acad Sci USA 1991; 88: 7759-7762.

10. Wagner JA, McDonald TV, Nghiem PT, et al. Antisense oligodeoxynucleotides to the cystic fibrosis transmembrane conductance regulator inhibit cAMP-activated but not calcium-activated chloride current. Proc Natl Acad Sci USA 1992; 89: 6785-6789.

11. Frizzell RA, Rechkemmer G, Shoemmaker RL. Altered regulation of airway epithelial cell chloride channels in cystic fibrosis. Science 1986; 233: 558-560.

12. Boucher RC, Cheng EHC, Paradiso AM, Stutts MJ, Knowles MR, Earp HS. Chloride secretory response of cystic fibrosis human airway epithelia. J Clin Invest 1989; 84: 1424-1431.

13. Knowles MR, Clarke LL, Boucher RC. Activation by extracellular nucleotides of chloride secretion in the airway epithelia of patients with cystic fibrosis. $N$ Engl $J$ Med 1991; 325: 533-538.

14. Mason SJ, Paradiso AM, Boucher RC. Regulation of transepithelial ion transport and intracellular calcium by extracellular ATP in human normal and cystic fibrosis airway epithelium. Br J Pharmacol 1991; 103: 16491656.

15. Bennett WD, Olivier KN, Zeman KL, Hohneker KW, Boucher RC, Knowles MR. Effect of uridine 5'-triphosphate plus amiloride on mucociliary clearance in adult cystic fibrosis. Am J Respir Crit Care Med 1996; 153: 1796-1801.

16. Zhang AL, Roomans GM. Ion transport in cultured pig tracheal submucosal gland acinar cells studied by X-ray microanalysis. Eur Respir J 1997; 10: 2204-2209.

17. Jaskulski D, Deriel JK, Mercer WE, Calabretta B, Baserga $\mathrm{R}$. Inhibition of cellular proliferation by antisense oligodeoxynucleotides to PCNA cyclin. Science 1988; 240: 1544-1546.

18. Thierry AR, Dritschilo A. Intracellular availability of unmodified, phosphorothioated and liposomally encapsulated oligodeoxynucleotides for antisense activity. Nucleic Acids Res 1992; 20: 5691-5698.

19. Cazenave C, Claude H. Antisense oligonucleotides. In: Mol JNM, Krol AR, eds. Antisense Nucleic Acids and Proteins. New York/ Basel, Marcel Dekker, 1991; pp. 4793.

20. Roomans GM. Quantitative X-ray microanalysis of biological specimens. J Electr Microsc Techn 1988; 9: 1944.

21. Grynkyewicz G, Poenie M, Tsien RY. A new generation of $\mathrm{Ca}^{2+}$ indicators with greatly improved fluorescence properties. J Biol Chem 1985; 260: 3440-3450.

22. Zhang AL, Martinez JR, Roomans GM. Effects of cholinergic and $\alpha$-adrenergic agonists on the monovalent ion content of rat submandibular gland acinar cells studied by X-ray microanalysis. Histochem Cell Biol 1997; 108: 149-153.

23. Culp DJ, Lee DKP, Penney DP, Marin MG. Cat tracheal gland cells in primary culture. Am J Physiol 1992; 261: L264-L275.

24. Yamaya M, Finkbeiner WE, Widdicombe JH. Ion transport by cultures of human tracheobronchial submucosal glands. Am J Physiol 1991; 261: L485-L490.

25. Yang CM, Farley JM, Dwyer TM. Acetylcholine-stimulated chloride flux in tracheal submucosal gland cells. $J$ Appl Physiol 1988; 65: 1891-1894.

26. Sasaki T, Shimura S, Wakui M, Ohkawara Y, Takishima T, Mikoshiba K. Apically localized IP3 receptors control chloride current in airway gland acinar cells. Am J Physiol 1994; 267: L152-L158.

27. McCann JD, Bhalla RC, Welsh MJ. Release of intracellular calcium by two different second messengers in airway epithelium. Am J Physiol 1989; 257: L116-L124.

28. Snouwaert JN, Brigman KK, Latour AM, et al. An animal model for cystic fibrosis made by gene targeting. Science 1992; 57: 1083-1088.

29. Yamaya M, Finkbeiner WE, Widdicombe JH. Altered ion transport by tracheal glands in cystic fibrosis. $\mathrm{Am} \mathrm{J}$ Physiol 1991; 261: L491-L494.

30. Yamaya M, Sekizawa K, Kakuta Y, Ohrui T, Sawai T, Sasaki H. P2u-purinoceptor regulation of chloride secretion in cultured human tracheal submucosal glands. $\mathrm{Am} \mathrm{J}$ Physiol 1996; 270: L979-L984.

31. Shimura S, Sasaki T, Nagaki M, Takishima T, Shirato K. Extracellular ATP regulation of feline tracheal submucosal gland secretion. Am J Physiol 1994; 267: L159L164. 